Jurnal Indonesia Sosial Teknologi: p-ISSN: 2723 - 6609

e-ISSN : 2745-5254

Vol. 2, No. 2 Februari 2021

\title{
VACCINATION IN THE FIGHT AGAINST COVID-19 AS A STATE DEFENSE
}

\section{Michelle Angelika S, Slamet Tri Wahyudi, Yohanes Firmansyah}

Faculty of Law, Pembangunan Nasional Veteran Jakarta, University, Jakarta, Indonesia Email: michelleangelika111@gmail.com, slamettriwahyudi@upnvj.ac.id

yohanesfirmansyah28@gmail.com

\begin{abstract}
Since the end of 2019 the world has been shocked by the emergence of the COVID19 virus, which spreads very quickly. Starting from the country of origin, namely the People's Republic of China, until in early March, Indonesia announced two positive cases of COVID-19. The COVID-19 pandemic is a threat to the Indonesian state. Various efforts have been made by the government to prevent and control the spread of this virus, ranging from restricting activities, maintaining distance, using masks, washing hands to developing vaccines. This effort is being carried out by the government as a form of state defense in fighting COVID-19. This research proves that COVID-19 is a social disaster that afflicts all walks of life, one of the methods for overcoming the Covid-19 outbreak by involving itself in the vaccination program organized by the authorities as a form of state defense.
\end{abstract}

Keywords: attitude of state defense; COVID-19; Vaccination

\section{Introduction}

Coronavirus is a virus that attacks the human respiratory system. The coronaviruses include extreme acute respiratory syndrome virus and Middle East respiratory syndrome virus that pose a widespread public health threat. Over the course of December, a group of people developed pneumonia which they were unable to recognize. In epidemiological terms, there has been a rise in consumption of seafood and animals in the region where the person is in close contact. (Bogoch et al., 2020)

The timeline of the Corona case is as follows; on December 18, 2019, 5 people were admitted to the hospital for respiratory complaints, one died. (Ren et al., 2020) According to health screening, on January 2, 2020, as many as 41 people were hospitalized with COVID-19 less than half of the people treated had comorbidities, such as diabetes, hypertension and heart disease. (Huang et al., 2020) According to the China National Health Commission Agency, the first 17 deaths were recorded on January 22, 2020. There have been 1975 confirmed cases of COVID-19 in mainland China with a total of 56 deaths as of January 25, 2020. As of January 30, 2020, 7734 confirmed cases were reported from China and 90 other confirmed cases occurred in a number of other countries, including Taiwan, Thailand, Vietnam, Malaysia, Nepal, Sri Lanka, Cambodia, Japan, Singapore, Republic of Korea, United Arab Emirates, United States of America, Canada, India, Australia, France and Germany. The case fatality rate based on statistics was 213/688. (Bassetti et al., 2020) 
The country of Indonesia, on March 2, 2020, announced the first 2 cases of Covid19. (Pranita, 2020) As of December 26, 2020 there were 629 confirmed cases, 429 confirmed cases and 19,111 deaths. (Satgas Penanganan COVID-19, 2020) As the number of Covid-19 cases increase, the number of isolation beds available for treatment is decreasing. This is consistent with the statement of Governor of South Jakarta regarding the available facility space used by up to $77 \%$ of all COVID-19 referral hospitals in the South Jakarta area. (CNN Indonesia, 2020)

The 7th President of the Indonesian Republic issued Government Regulation Number 21 of 2020 which placed large scale social restrictions to contain the COVID-19 pandemic in Indonesia.. (Peraturan Pemerintah Nomor 21 Tahun 2020 Tentang Pembatasan Sosial Berskala Besar (PSBB) Dalam Rangka Percepatan Penanganan COVID-19, 2020) In addition, the government of Indonesia has also set up a task force to oversee handling COVID-19 in Indonesia, including how to quarantine and isolate people who may have come into contact with COVID-19.

Given the rapid spread of COVID-19 and the dangers that will arise if it is not treated immediately, one possible way to prevent the spread of this virus is to develop a vaccine. Vaccines protect both those who receive them and those that are not vaccinated against a given disease. Despite having no SARS or MERS vaccine, a SARS - and MERSvaccine was found first. The development of a vaccine against a serious disease is essential because it will prevent the spread and ultimately prevent the disease from spreading. Additionally, because the virus rapidly spreads, a vaccine needs to be administered in a brief time period to limit its spread. In reaction to this, the Indonesian government is also actively involved in planning vaccination activities that will be given to the community. President Joko Widodo (Jokowi) signed the Presidential Regulation of the Republic of Indonesia Number 99 of 2020 concerning Vaccines Procurement and Implementation of Vaccinations in the Context of Combating the 2019 Corona Virus Disease (COVID-19) Pandemic to regulate the government's, ministries and agencies' vaccination activities.

Until now, the world is competing in creating the COVID-19 vaccine, especially the country of origin of the spread of the COVID-19 virus, namely China by issuing one type of COVID-19 vaccine, namely "Sinovac" which with various considerations from the government of the Republic of Indonesia chose the vaccine. the shot will be administered in Indonesia. The people of Indonesia are now being plagued by various issues, hoaxes, and a sense of distrust of the government in making the decision to use the COVID-19 vaccine to combat the COVID-19 outbreak in Indonesia.

This paper discusses the perspective of the people of the Republic of Indonesia regarding the COVID-19 vaccination which will be held by the government of the Republic of Indonesia in the form of State Defense efforts in fighting COVID-19 in a review from the field of state defense.

\section{Method and Materials}

The research method was in the form of a normative legal and sociology review that studied the application of values in positive law by analyzing regulations related to the "vaccination in the fight against COVID-19 As A state defense" using various approaches: statute approach, conceptual approach, and case approach. 


\section{Results And Discussion COVID-19}

A person exposed to the covid-19 virus will experience symptoms from lightweight to death on day 6 to day 41 with an average of around day 14. The duration of this time depends on various factors, one of which is the age and immunity of the person's immune system .(Wang et al., 2020) Symptoms that arise can be classified into two, namely systemic symptoms and respiratory symptoms. Systemic symptoms include; fever, cough, and fatigue, sputum production, headache, hemoptysis, acute cardiac injury, hypoxemia, dyspnea, lymphopenia, and diarrhea. Meanwhile, respiratory symptoms are; rhinorrhoea, sneezing, and sore throat, pneumonia, RNAaemia, and acute respiratory distress syndrome. In radiological supporting examinations in the form of; Chest X-ray revealed infiltration in the upper lobe of the lung associated with increased dyspnea with hypoxemia, chest CT scan revealed bilateral ground-glass opacities. (Lei et al., 2020)

The following are terms used by the Indonesian Health Ministry that classify the Indonesian COVID-19 positive patients into two groups, People Without Symptoms, who are those who have no complaints but have a risk of being infected by COVID-19 positive patients or those who without complaint are contacts. closely related to positive cases of Common Variable Indicators. People Under Monitoring are those who have complaints of fever, a history of fever, or complaints in the respiratory system and there is a history of traveling to a positive country for COVID-19 within the past fourteen days or those who have complaints of the respiratory system and have contact with COVID-19 patients in the past fourteen days. Patients Under Supervision are those with ispa plus one of the respiratory complaints and there is a history of traveling to a positive country with COVID-19 in the past fourteen days, or those with high fever, or ispa and there is contact with a positive COVID-19 patient. The average cases of 19 within the past fourteen days, for those with severe pneumonia and no other cause. The confirmations were patients who were positive for COVID-19 using the gold standard method for COVID-19. (Gugus Tugas Percepatan Penanganan COVID-19, 2020)

On July 13, 2020, the health ministry legally exchanged the old terminology into suspect cases, probable cases, close contacts and confirmed cases. Suspected cases are those who live in areas where the spread of COVID-19 is declared and have respiratory complaints, or those who have had close contact with confirmed cases within the past fourteen days, or those who are being treated in hospital with severe ispa without a definite cause. Probable cases are those who have complaints of severe ispa and have a strong suspicion that it leads to COVID-19 but the gold standard examination for COVID19 has not been carried out. Close contacts are anyone the patient comes into contact with. Cases confirmed positive for COVID-19 are those who were identified as COVID-19 positive based on the COVID-19 gold standard screening tool. .(Rokom, 2020)

\section{VAKSINASI}

The word "vaccine" comes from Latin (Cowpox) which was originally used to prevent smallpox (Plotkin, 2013). Vaccines are preparations of dead or weakened pathogens, or their products that stimulate the production of antibodies without causing disease. Vaccinations involve your immune system, which are called active immunizations. Passive immunity is the injection of antibodies formed by other animals (eg horses, humans) that provide temporary protection. (Okafor, 2007) 
Antigens trigger an immune response. Antigens can be proteins, polysaccharides or lipid conjugates with proteins (lipoproteins) (glycolipids). Antibodies recognize antigens in a certain way and a memory is acquired. Primary response is the first encounter with an antigen. Reunion with the same antigen causes a stronger immune response. The function of the vaccine is to encourage memory B cells to multiply and produce antibodies. (Okafor, 2007)

Vaccines are usually produced from viruses and bacteria (Bacterial vaccines). Viruses can be used to make vaccines. Or, viruses can be used only as "vaccine" genes. Cells can be either alive or dead. Its pathogenicity has been diminished. If a live vaccine is used, recipients have long-term immunity. If a non-live vaccine is used, recipients have only short-term immunity. It is necessary to repeat vaccination. Vaccines may be in the form of a toxoid, a specific protein, a polysaccharide, a nucleic acid, or a conjugate. Vaccines that have been killed (Inactivated Vaccines), vaccines that contain toxoid, and vaccines that contain sub-units of antigens (Vaccines sub-units) (Worl Health Organization, 2013)

Vaccine production and propagation generally includes four basic stages, namely: Breeding includes the multiplication (or amplification) of the microorganisms used for vaccine production. Isolation includes the separation of living cells or growth media at the breeding stage. Purification removes materials that could be carried during the isolation process or selectively separates parts of the living microorganisms used as vaccines. Formulation includes mixing of the purification product solution to obtain desired concentration. We have added a preservative to some vaccines to prevent the risk of bacteria infecting the vaccines. At the end of the manufacturing process, the vaccine is packaged for delivery to a healthcare provider. (Plotkin, 2013)

Several vaccine production processes can be seen in the following figure: Based on the MUI fatwa No. 4 of 2016 that immunization or vaccination is basically permissible (mubah) as a form of effort to realize immunity (immunity) and prevent the occurrence of certain diseases. This fatwa was published to overcome the doubts of Muslims in Indonesia about the immunization law. Even though the MUI fatwa has been issued, it does not guarantee that all Muslims in Indonesia carry out immunizations. There are still groups that reject immunization because one of the reasons is that there is an element of pork in the vaccine manufacturing process. This reason cannot be generalized that all vaccines contain elements of pork. Because basically vaccines that involve enzymes derived from pigs, there are only a few types of vaccines. One example of a vaccine that involves enzymes derived from pigs is the meningitis vaccine. (Majelis Ulama Indonesia, 2016)

\section{Anti-Vaccine Movement Arguments}

Anti-vaccine has become a global movement. Indonesia is one of the countries where food-borne illness outbreaks happen. The arguments used in the rejection of vaccines or immunizations are similar from one region to another. The same is true in Indonesia. This suggests that anti-vaccine groups in Yogyakarta are similar to anti-vaccine groups in Jakarta and other cities. (Muallifah, 2018)

Some of the arguments that are often used by anti-vaccine groups are the hadith tahnik above. Tahnik is an immunization method that was exemplified by the Prophet for Muslims. Islam is a religion whose teachings are perfect. So there is no need for other methods, let alone those from infidels. According to them, Nabii as a role model for 
Muslims has actually exemplified one of the most superior methods of vaccination, because it comes from the teachings of prophetic guidance revealed by Allah, namely tahnik. There is no need to add more. The vaccines used to vaccinate are products that are impure and illegitimate, because the production process involves pork. Whereas in the Al-Qur'an it is clear that pigs are unclean animals. Thus, inserting a vaccine into the body is tantamount to introducing a pig into the body. This clearly contradicts the Koran. The vaccination program originates from the infidels of the Jews, which is intended to weaken generations of Muslims. (Muallifah, 2018)

\section{ATTITUDE OF STATE DEFENSE}

Patriotism is a concept drawn up by lawmakers and state officials regarding patriotism of a person, a group or all components of a country. Everyone must be ready to defend the country. The love for one's country is a manifestation of a person's life. Someone is born, grows up, and in his effort to make a living. Every citizen has the right and obligation to defend the state, and defense will be regulated by law. A willingness to serve and defend the country is one of the prerequisites for being part of the country. The country's defense spectrum was wide, from the smoothest to the fiercest. Jointly protecting the integrity of citizens from the threat of an armed enemy. To act and to do the best for the nation and the state. (Bakesbangpol, 2013; Irfani, 2015; Rahayu et al., 2019; Soepandji \& Farid, 2018; Timbul, 2016; Umra, 2019; Widodo, 2011)

The state defense process is regulated in law in Indonesia. Also in the Pancasila and the 1945 Constitution, especially article 30. Defending the nation is the obligation of all Indonesian people without exception. Doing your duty to defend the country is evidence of being willing to serve the country, and shows that you are aware of sacrificing yourself to defend the country. The understanding of state defense is very broad, ranging from subtle to hard. (Bakesbangpol, 2013; Irfani, 2015; Rahayu et al., 2019; Soepandji \& Farid, 2018; Timbul, 2016; Umra, 2019; Widodo, 2011)

There are also several other legal bases and regulations regarding compulsory state defense, namely, MPR Decree No. VI of 1973 concerning the concept of Archipelago Insights and National Security. Law No.29 of 1954 concerning the Principles of People's Resistance, Law No.20 of 1982 concerning Basic Provisions for the Defense and Security of the Republic of Indonesia. Amended by Law No. 1 of 1988. MPR Decree No. VI of 2000 concerning the Separation of Military from Police. MPR Decree No. VII of 2000 on the Role of the TNI and POLRI. Amendments to the 1945 Constitution Article 30 paragraphs 1-5 and Article 27 paragraph 3. Law No.3 of 2002 concerning National Defense. Law No.56 of 1999 concerning Trained People.

Some of the objectives of defending the state include: (1) Maintaining the survival of the nation and state (2) Preserving culture and carrying out the values of Pancasila and the 1945 Constitution (3) Doing the best for the nation and state (4) Maintaining the identity and integrity of the nation / The following are some of the benefits that can be obtained from defending the country: (1) Establishing a disciplined attitude when activities and other activity arrangements. (2) Forming a spirit of togetherness and solidarity among fellow comrades in arms. (3) Build mentally and physically strong. (4) To instill a sense of love for the Nation and Patriotism according to one's abilities. (5) Train leadership in leading themselves and groups. (6) Establishing faith and piety in the religions adhered to by individuals. (7) Devoted to parents, nation and religion. (8) Train individual speed, agility and accuracy in carrying out activities. (9) Eliminating negative 
attitudes such as laziness, apathy, wastefulness, selfishness, and undisciplinedness. (Bakesbangpol, 2013; Irfani, 2015; Rahayu et al., 2019; Soepandji \& Farid, 2018; Timbul, 2016; Umra, 2019; Widodo, 2011)

Some examples of state defense in real life, namely siskamling, maintaining cleanliness, preventing the dangers of drugs, preventing fights between individuals and groups, increasing agricultural output so that regional and national food availability is sufficient, love domestic production in order to increase export output, preserve Indonesian culture and appearing as the nation's children who excel both nationally and internationally. Awareness of defending the country is essentially a willingness to serve the country and willingness to sacrifice to defend the country. The spectrum of that country's defense was very wide, from the smoothest, to the most violent. Starting from good relations among citizens to jointly warding off the real threat of armed enemies. This includes being able to act and do the best for the nation and state. (Bakesbangpol, 2013; Irfani, 2015; Rahayu et al., 2019; Soepandji \& Farid, 2018; Timbul, 2016; Umra, 2019; Widodo, 2011)

\section{Government Efforts to Combat COVID-19 as a Form of State Defense}

The Indonesian government, through the Ministry of Health, has taken various steps to prevent the entry of COVID-19 into the territory of Indonesia, namely: 1. Issued circular letters to all Provincial and District / City Health Offices, Referral Hospitals, Port Health Offices, and Balai Environmental Health Engineering, to increase vigilance and preparedness in facing the possibility of the entry of this disease, 2. Placing 135 thermal scanners at all airports in Indonesia, especially those with direct flights from the People's Republic of China (PRC), 3. Providing health alert cards and Communication, Information and Education (IEC) to passengers, 4. Designating at least 100 Referral Hospitals previously used in cases of bird flu and preparing 21 evacuation capsules (patient isolation push tables) as a precautionary measure. Then the Ministry of Health also opened a service contact that could be accessed by the public to find information about the corona virus. Contact information service numbers are 0215210411 and +6281212123119. (Kementrian Luar Negeri Republik Indonesia, 2020)

On February 2, 2020, the Indonesian government announced: a ban on all Indonesian airlines' and ships' flights to and from China, with the exception of special flights for business purposes; that all Chinese citizens are prohibited from entering Indonesia; and that all Indonesian animal imports from China have been suspended. It has been determined that the government needs to repatriate citizens from Hubei Province, China. The following steps have been taken for Indonesian citizens:

1. To assist Indonesian citizens in buying food and supplies in Wuhan, the Chinese government has instituted policies that restrict movement of visitors from the PRC, forcing embassy staff to manage their relocation to Wuhan. 2. 10,000 N-95 masks were sent from Indonesia through the Ministry of Foreign Affairs and the Indonesian Embassy in Beijing. 3. Coded volunteers: 237 Indonesians and 1 foreigner who were in Hubei province on February 1-2, 2020. 4. From February 2, 2020, every Indonesian citizen and 5 aju teams from the Indonesian Embassy in Beijing have gone through 14 days (virus incubation period) at the Natuna Air Force Base. 4. The Indonesian citizens had completed their 14 day observation quarantine period, and were declared healthy, free from the corona virus. (Kementrian Luar Negeri Republik Indonesia, 2020) 
The government is working to get vaccines from several countries to tackle COVID-19. The state seeks to manage vaccination starting from the funding, procurement and distribution of vaccines. It is in accordance with Presidential Regulation Number 99 of 2020 concerning Vaccines Procurement and Implementation of Vaccinations in the context of the COVID-19 Pandemic, which was signed on October 5, 2020. The Minister of Health is required to conduct procurement and implementation of vaccines. In keeping with the mandate of the Presidential Decree, the Minister of Health is considering the views and input of the COVID-19 Committee. The ministry has prepared two Draft Permenkes on Vaccine Procurement and Immunization in the context of the COVID-19 pandemic. Process and procure. RPMK is discussed across programs and sectors in internal and external procurement. (Kementrian Kesehatan Republik Indonesia, 2021)

Efforts to procure vaccines have been carried out by the Indonesian Minister of Health together with the Minister of Economy, Maritime and Investment, the Minister of Foreign Affairs and the Minister of BUMN so that Indonesia has access to vaccine candidates for Sinovac (PRC), Sinopharm (PRC) and Astra Zeneca (UK). In addition to the bilateral cooperation mechanism, in finding vaccine sources, the Government is also collaborating with international organizations / alliances, namely the Coalition for Epidemic Preparedness Innovations (CEPI) and the Global Alliance for Vaccine and Immunization (GAVI). In Indonesia alone, Indonesian researchers are also developing a Red and White Vaccine using an Indonesian virus strain. "While waiting for the Red and White vaccine, which is expected to be ready in early 2022, we will take advantage of the cooperation with China and Britain. Because this vaccine requires $2 x$ injections, we need to set priorities for vaccine administration. We prioritize the Front Guard Health Workers, "explained Minister of Health Terawan on the sidelines of a visit to China. The government is targeting vaccines from China and the UK to cover a minimum coverage of $70 \%$ of the Indonesian population. Apart from vaccines from the international organization / alliance CEPI and GAVI, it will guarantee access to vaccines for $20 \%$ of Indonesia's population, Red and White vaccine readiness which is expected to cover $100 \%$ of Indonesia's population. On the other hand, the Government is also actively campaigning for 3M's behavior to break the chain of spreading the virus, namely wearing masks, washing hands and maintaining distance. Apart from 3M's behavior, people are also asked to be self-aware to avoid crowds, keep exercising for 30 minutes every day, consume balanced nutrition, and manage stress. (Kementrian Kesehatan Republik Indonesia, 2021)

\section{Conclusion}

The COVID-19 virus, which spreads very quickly, has shocked the world since the end of 2019. Since the original epidemic in China, which actually started as the People's Republic of China in May of 2012, Indonesia has reported two positive cases of the CoVid-19 virus, one virus found in the country of China. As a threat, the COVID-19 pandemic could cause problems for the Indonesian state. Since numerous attempts have been made by the government to prevent and control the spread of the virus, some of which range from restricting activities, maintaining distance, using masks, washing hands, and developing vaccines. As this new research proves, COVID-19 is and will be an extremely social problem that afflicts all walks of life, and one of the methods of 
Michelle Angelika S, Slamet Tri Wahyudi, Yohanes Firmansyah

overcoming the Covid-19 outbreak is to get involved in the vaccination program organized by the authorities. 


\section{Bibliografi}

Bakesbangpol. (2013). Bela negara. Journal of Chemical Information and Modeling.

Bassetti, M., Vena, A., \& Giacobbe, D. R. (2020). The novel Chinese coronavirus (2019$\mathrm{nCoV}$ ) infections: Challenges for fighting the storm. European Journal of Clinical Investigation, 50(3). https://doi.org/10.1111/eci.13209

Bogoch, I. I., Watts, A., Thomas-Bachli, A., Huber, C., Kraemer, M. U. G., \& Khan, K. (2020). Pneumonia of unknown aetiology in Wuhan, China: potential for international spread via commercial air travel. Journal of Travel Medicine, 27(2). https://doi.org/10.1093/jtm/taaa008

CNN Indonesia. (2020, September). Jakarta Darurat Covid: Rumah Sakit Krisis dan Kematian Tinggi. CNN Indonesia.

Gugus Tugas Percepatan Penanganan COVID-19. (2020). Pedoman Penanganan Cepat Medis dan Kesehatan Masyarakat COVID-19 di Indonesia. Gugus Tugas Percepatan Penanganan COVID-19.

Huang, C., Wang, Y., Li, X., Ren, L., Zhao, J., Hu, Y., Zhang, L., Fan, G., Xu, J., Gu, X., Cheng, Z., Yu, T., Xia, J., Wei, Y., Wu, W., Xie, X., Yin, W., Li, H., Liu, M., ... Cao, B. (2020). Clinical features of patients infected with 2019 novel coronavirus in Wuhan, China. The Lancet. https://doi.org/10.1016/S0140-6736(20)30183-5

Irfani, A. (2015). SEMANGAT BELA NEGARA. Jurnal IAIN Pontianak.

Kementrian Kesehatan Republik Indonesia. (2021). Kemenkes Laporkan Upaya Pemerintah dalam Menyediakan Akses Vaksin COVID-19.

Kementrian Luar Negeri Republik Indonesia. (2020). Langkah Dan Upaya Pemerintah Indonesia Dalam Menangani Dan Menghadapi COVID-19.

Lei, J., Li, J., Li, X., \& Qi, X. (2020). CT Imaging of the 2019 Novel Coronavirus (2019nCoV) Pneumonia. Radiology, 295(1), 18-18. https://doi.org/10.1148/radiol.2020200236

Majelis Ulama Indonesia. (2016). Fatwa Majelis Ulama Indonesia Nomor 04 Tahun 2016 Tentang Imunisasi. 4.

Muallifah, A. Y. (2018). Mengurai Hadis Tahnik dan Gerakan Anti Vaksin. Jurnal Living Hadis, 2(2), 253. https://doi.org/10.14421/livinghadis.2017.1334

Okafor, N. (2007). Modern Industrial Microbiology and Biotechnology. In Industrial (Vol. 3, Issue 12).

Plotkin, S. A. (2013). Vaccine Fact Book. University of Pennsylvania. 
Michelle Angelika S, Slamet Tri Wahyudi, Yohanes Firmansyah

Pranita, E. (2020). Diumumkan Awal Maret, Ahli: Virus Corona Masuk Indonesia dari Januari. Kompas.Com.

Rahayu, M., Farida, R., \& Apriana, A. (2019). Kesadaran Bela Negara Pada Mahasiswa. Epigram. https://doi.org/10.32722/epi.v16i2.2232

Ren, L.-L., Wang, Y.-M., Wu, Z.-Q., Xiang, Z.-C., Guo, L., Xu, T., Jiang, Y.-Z., Xiong, Y., Li, Y.-J., Li, X.-W., Li, H., Fan, G.-H., Gu, X.-Y., Xiao, Y., Gao, H., Xu, J.-Y., Yang, F., Wang, X.-M., Wu, C., ... Wang, J.-W. (2020). Identification of a novel coronavirus causing severe pneumonia in human. Chinese Medical Journal, 133(9), 1015-1024. https://doi.org/10.1097/CM9.0000000000000722

Peraturan Pemerintah Nomor 21 Tahun 2020 tentang Pembatasan Sosial Berskala Besar (PSBB) Dalam Rangka Percepatan Penanganan COVID-19, (2020).

Rokom. (2020). Kemenkes Siap Sosialisasikan Perubahan Istilah ODP, PDP dan OTG ke Seluruh Dinas Kesehatan. Kementrian Kesehatan Republik Indonesia.

Satgas Penanganan COVID-19. (2020). Peta Sebaran. Satuan Tugas Penanganan COVID-19.

Soepandji, K. W., \& Farid, M. (2018). KONSEP BELA NEGARA DALAM PERSPEKTIF KETAHANAN NASIONAL. Jurnal Hukum \& Pembangunan. https://doi.org/10.21143/jhp.vol48.no3.1741

Timbul, S. (2016). Bela Negara Dan Kebijakan Pertahanan. Majalah WIRA.

Umra, S. I. (2019). Penerapan Konsep Bela Negara, Nasionalisme Atau Militerisasi Warga Negara. Jurnal Lex Renaissance. https://doi.org/10.20885/jlr.vol4.iss1.art9

Wang, W., Tang, J., \& Wei, F. (2020). Updated understanding of the outbreak of 2019 novel coronavirus (2019-nCoV) in Wuhan, China. Journal of Medical Virology, 92(4), 441-447. https://doi.org/10.1002/jmv.25689

Widodo, S. (2011). Implementasi bela negara untuk mewujudkan nasionalisme. Jurnal Ilmiah Civis.

Worl Health Organization. (2013). Vaccine Safety Basic Learning Manual. Worl Health Organization, 207. 